adulterated article commend us to Bousset. Foster and Schmidt are only disciples, for Bousset is their master. This is the new evangel of ignorance which is to save the people.

Bousset knows finally that Jesus never used the term Son of God about himself (p. 182), that he did call himself Son of Man a few times only (p. 193 f.), that he "never overstepped the limits of the purely human" (p. 202), and "did not thereby place himself on a level with God" (p. 203). Bousset admits that these are "tortuous paths" (p. 195), but he becomes positively offensive when he speaks of the "broodings" of Jesus (p. 195).

A. T. Robertson.

\title{
The Book of the Revelation.
}

By C. Anderson Scott. New York, A. C. Armstrong \& Son, 1906* Price \$1.25.

Mr. Scott edited the volume on Revelation in the Century Bible, and it was one of the best of the series. The same thing is true of this volume in the Practical Commentary. He is an alert scholar, with a wholesome sanity of outlook. Mr. Scott accepts at most points Prof. Ramsay's view in the Letters to the Seven Churches, but thinks the second beast is not the Provincial Power, but the Priestly Cult. He sees the legend of Nero redivivus in the beast that was, is not, and is to come-a matter by no means certain. The book has many sensible observations, and at once ranks with the best of the commentaries on Revelation.

A. T. ROBERTSON.

The Making of the Gospels. Six Lectures Delivered During Lent, 1905, in Manchester Cathedral.

By Rev. J. J. Scott, M. A., Canon of Manchester. London, John Murray, Albmarle St. West. Pp. 112, paper $\$ 1.00$ net.

These lectures profess to give a summary of the best English Biblical Criticism. From the facts concerning the four oldest Bibles - the Old Greek Text, the Old Latin and Syriac Versions, and the Diatesseron - the author con- 
cludes (1) that the Gospels were written within the period when their reputed authors lived; (2) that the Church was inspired to include all four in her volume of Gospels, and that the authors were inspired what to include in their several works. He dates Mark 63, Matthew and Luke 70, John 96. Mark is accepted as the basis of Matthew and Luke. Their portrait of Christ is his, and his is Peter's. We have only two portraits ; the other is John's. Peter's is the Human side; John's the Divine.

The last four lectures deal with the sources, object and characteristics of each of the Gospels. It is refreshing to find Textual Criticism given its proper authority-that is the author's guiding principle. Early true interpretations are referred to the school founded by John at Ephesus. Very interesting is Canon Scott's conjecture of Luke's connection with, and indebtedness to John. More can be said for it than for most of the conjectures one meets with.

The book is popular, very racy and readable, fresh and interesting, and, barring a bit of its churchiness, judicious. One could wish it wide circulation. For it is sane and scholarly, holds close to facts, and confirms faith in the Bible as the Word of God.

J. H. Farmer.

\section{Johannine Grammar.}

By Edwin A. Abbott. Adam \& Charles Black, Soho Square, London, England, 1906. Pages 687. Price 16s. 6d.

This is the most valuable of the six parts of Diatessarica. It is in fact a grammatical commentary of a very high order, and far more helpful than many of the perfunctory commentaries. Here an effort is made to understand the language of the writer. There are many significant things in John's Gospel such as his use of terms, his repetitions, his use of the pronouns, his prepositions, his use of $x a i$, so often and to mean "and yet," his use of iva, etc. In this volume also Dr. Abbott's rich scholarship comes out with fine originality. He has not simply read widely, he has ideas in abundance on a multitude 